Nr 2(65), 2020, s. 327-337

https://doi.org/10.12797/Politeja.17.2020.65.23

\author{
Aleksandras ŠTROMAS
}

\title{
POEZJA I POLITEJA
}

W rozmowie, która odbyła się podczas VI Sympozjum Litewskiej Nauki i Sztuki w Chicago (23-26 listopada 1989 roku), rozważano problemy relacji między sztuką i polityką oraz kulturą i religią. Sztuka jest nie tylko krytycznym stosunkiem wobec systemów opartych na dominacji (przede wszystkim totalitarnych), ale również wyrazem autentycznego stanu człowieka - powiedział dr Aleksandras Štromas. Według niego obecnie znajdujemy się w kryzysie duchowym o renesansowych korzeniach i dążymy do powrotu do religijności.

Vaidotas Daunys: Wczoraj zakończyliśmy rozmowę na myśli, że polityk czasem musi czytać wiersze - te, które wyrażają coś wspólnego dla całego narodu albo społeczeństwa. Słowem, chodzi o poezję, która jest elementarna i łatwa. Jednak kultura, która obecnie na Litwie chce odzyskać pozycję i zaczyna odgrywać rolę polityczną, częściowo pozostała w opozycji. Przecież przez te dziesięciolecia kształtowała się ona nie tylko jako, na przykład, poezja łatwa i zrozumiała dla narodu, ale w istocie również jako poezja elitarna. Czy możliwa jest kultura elitarna i zarazem odzwierciedlająca oczekiwania narodu?

Aleksandras Štromas: Społeczeństwo i naród składają się z pewnych tradycji kulturowych: tradycji ludowych, pieśni czy jakiejś zrozumiałej dla wszystkich poezji. To wspólne dziedzictwo jest tym, co pozwala nam - członkom jednej wspólnoty, jednej grupy etnicznej i jednej kultury - swobodnie się komunikować. Kiedy mówimy Lietuva brangi, mano tevyn $e^{1}$, to wszyscy wiemy, co to oznacza i z czym to powiedzenie łączy się w kontekście kultury litewskiej, ale zapewne żaden człowiek postronny nie zrozumie tego zdania tak, jak my. Kultura zatem, jako środek komunikacji, jako środek konsolidacji narodu, jest wspólna dla wszystkich członków tego narodu. Jest to kultura wspólnotowa. Jeśli chodzi o poezję elitarną, w której igra się formami i poprzez bardzo skomplikowane niuanse próbuje się wyrazić jakieś wyjątkowo abstrakcyjne znaczenia, to jest ona, oczywiście, chlebem jedynie dla intelektualistów, ale nie jest odpowiednia

Lit. Litwo droga, moja ojczyzno. Fragment patriotycznego wiersza poety litewskiego Maironisa. Wszystkie przypisy pochodzą od tłumacza. 
dla zwykłych ludzi, nawet do komunikacji. Jednak w warunkach, gdy komunikacja za pomocą naturalnych środków kulturowych jest niemożliwa, kiedy tożsamość narodu jest zrujnowana, skrępowana albo w inny sposób zniewolona, to nagle pojawia się nowa funkcja kultury. Podejmowane są starania, aby poprzez kulturę stworzyć nowy sposób komunikacji, autentyczny, nie ten, który jest narzucony, ale taki, który mógłby zostać przyjęty przez naród. I niezależnie od tego, jaką tworzono by poezję, prozę czy inne dzieła sztuki w takiej sytuacji, to zawsze odgrywają one, nawet będąc w swojej formie elitarnymi, rolę tego nowego sposobu komunikacji. Kultura zawsze wyraża autentyczność i dlatego nawet najbardziej elitarna poezja czy literatura w ogóle - a w warunkach ucisku autentyczna kultura musi być podstępna, skomplikowana i elitarna, ponieważ inaczej nie pokona barier stworzonych przez ucisk - musi stać się masowa i ponownie wspólna dla wszystkich. W tym sensie można powiedzieć, powtarzam, że dla zniewolonego społeczeństwa twórczość poetycka i artystyczna - oryginalna i profesjonalna, a nie tylko folklorystyczna - jest koniecznością i naturalnym zamiennikiem dla innych zwyczajnych (politycznych, społecznych itd.) funkcji narodu, które w normalnych warunkach zazwyczaj wykonywane są bez pomocy twórczości artystycznej. W ten sposób twórczość artystyczna staje się surogatem innych naturalnych funkcji narodu.

V.D.: Kultura albo, konkretnie, poezja rzeczywiście u nas często spełniała tę właśnie funkcję polityczną. Jak każdy dobry albo niekoniecznie dobry polityk wyrażała nie tyko to, co wypowiadała, ale również to, co przemilczała. I przez to ta nasza poezja była bardzo polityczna. Chcę tylko zapytać, czy zgodziłby się Pan z myślą, że w okresie - dotychczas u nas dominującym - w którym nie było ani państwowej, ani ekonomicznej suwerenności, kultura (a nie tylko poezja) w swoisty sposób rekompensowała brak suwerenności?

A.Š.: Suwerenność to ścisłe pojęcie, nie należy używać go tak szeroko. Suwerenność może być określona jako nadrzędność narodu, jako taka władza, ponad którą nie ma żadnej innej. Suwerenność jest zatem najwyższym, niemal absolutnym samostanowieniem. Jeśli suwerenność narodu jest zanegowana, to jego naturalną, wprost instynktowną reakcją na taką sytuację jest próba przetrwania w nieprzychylnych warunkach i przedłużenie swojego istnienia tak, aby z czasem bez wielkiej straty można było odtworzyć również suwerenność. I odpowiednio funkcja integralności tego narodu, która w warunkach suwerenności realizowana jest na inne sposoby, nagle przypada twórczości artystycznej. Teraz druga sprawa. Mając na uwadze to, co mówił Pan o naszej konkretnej kulturze, która nie zawsze wszystko wypowiadała, coś przemilczając, chciałbym podkreślić, że takie przemilczenia zawierają czasem dość niebezpieczne elementy. Pamiętam na przykład wystawioną w wileńskim Państwowym Teatrze Dramatycznym sztukę Mindaugas Justinasa Marcinkevičiusa ${ }^{2}$. Wprost z zadziwieniem obserwowałem entuzjastyczną reakcję publiki na po raz pierwszy usłyszane w niej słowo „Litwa” bez

2 Justinas Marcinkevičius (1930-2011) to jeden z najważniejszych literatów litewskich późnego okresu radzieckiego. Mindaugas z 1968 roku to pierwsza część wierszowanej trylogii dramatycznej (kolejne części to Mažvydas i Katedra). Sztuki te określane są czasem eposem narodowym ze względu na silny ładunek emocji patriotycznych i „panoramiczne” ujęcie losów narodu w najważniejszych dla niego momentach. 
dopowiedzenia „sowiecka”. Pochwycona przez rozbudzone emocje narodowe, nasza publika bezwarunkowo przyjęła wyrażoną w Mindaugasie myśl, że „w imię Litwy”, bez dopowiedzenia „sowieckiej”, można i należy poświęcić wszystko, nawet najważniejsze wartości, ponieważ najważniejszą wartością jest właśnie Litwa i w jej imię, „w imię Litwy" warto nie tylko umierać, ale i zabijać, podstępnie knować, oszukiwać i odrzucić elementarne zasady uczciwości. Usprawiedliwiający amoralność (oczywiście w imię „wspólnego dobra”) Mindaugas stał się symbolem i fundamentem zjednoczenia narodu. Kiedy jednak pomyślimy o sytuacji, w której sztuka ta ujrzała światło rampy i trafiła do wydawnictw, przypomnimy sobie, że w Związku Sowieckim była wówczas bardzo silna tendencja do rehabilitacji Stalina. I co się stało? Dostaliśmy litewski dramat, który głęboko poruszył naród, jednak w swoim morale stał się jakby przeciwstawieniem Szekspirowskiego Makbeta. W Makbecie Szekspir twierdzi, że cel nie uświęca środków, że amoralne środki przeczą najmoralniejszym nawet celom, a jednocześnie nieuchronnie uśmiercają duchowo władcę, który rozmija się z moralnością, i zamieniają go w siedzącego na tronie i siejącego śmierć potwora. Tej wprost przerażającej amoralności dramatu Marcinkevičiusa naród, jak się zdaje, nie zauważył. Przytłoczony wieloma latami zniewolenia, był gotowy chciwie połknąć jakiekolwiek autentycznie brzmiące patriotyczne zawołanie, zwłaszcza gdy to zawołanie, ogłaszane w artystycznej formie, wzmocnione było autorytetem prawdziwej sztuki. Jednak naród nie pojął tego, że to zawołanie przeczyło standardom świadomości cywilizowanego człowieczeństwa i odzwierciedlało barbarzyńską moralność, którą Europa odrzuciła już w czasach Szekspira. I wydaje mi się, że kiedy sztuka zastępuje w społeczeństwie wszystkie funkcje - i politykę, i indywidualną inicjatywę ekonomiczną, i działalność charytatywną itp. - pojawia się wiele podwodnych kamieni, na których bardzo łatwo można się potknąć. Zapewne nieraz poślizgnęliśmy się w ten sposób z powodu litewskiej sztuki radzieckiej. W kontekście literatury i sztuki litewskiej takie „artystyczne poślizgnięcia” były może nawet bardziej widoczne niż, na przykład, w kontekście literatury i sztuki rosyjskiej. Bowiem w Rosji wręcz rozkwitał samizdat, którego na Litwie praktycznie nie mieliśmy. Każdy szanujący się litewski pisarz swoje utwory koniecznie chciał drukować w wydawnictwach państwowych, coś w nich przemilczając albo tak je szlifując, aby spełniały oficjalne wymagania. Takie nastawienie naszych twórców kultury bardzo zaszkodziło kulturze litewskiej. Na Litwie nie stworzono, niestety, wysokiej kontrkultury. Wszystko, co miało spełnić funkcje „drugiej” kultury, czyli kontrkultury, szło przez „pierwsze”, czyli oficjalne kanały, a to osłabiało proces kulturowy, nadawało mu dwuznaczność, czasem nawet groźną dla ciągłości samej kultury narodowej.

V.D.: Mimo wszystko zadam ponownie to bolesne pytanie - czy politykę da się pogodzić z moralnością?

A.Š.: Dobra polityka zawsze jest moralna. Kłamstwo ma krótkie nogi nie tylko w stosunkach międzyludzkich, ale również w stosunkach pomiędzy narodami i państwami. Rezultaty amoralnej polityki nigdy nie bywały trwałe. Amoralna polityka może, oczywiście, osiągnąć dość dobre rezultaty tymczasowe, ale z biegiem czasu i tak

Cytat z Pieśni narodowej Vincasa Kudirki, czyli hymnu narodowego Litwy. 
przegrywa. Wniosek ten potwierdza cała historia ludzkości - od starożytnego Egiptu i czasów greckich aż po to, co widzimy dzisiaj w świecie komunistycznym.

V.D.: Czy wierzy Pan, że polityk może czuć wyrzuty sumienia, że poczucie winy może być dla niego wyjątkowo ważne i że może on budować na tym swoje działania i swoją politykę?

A.Š.: Wydaje mi się, że każdy ważniejszy działacz polityczny wyznacza sobie jakieś w jego opinii szlachetne - zadanie. Dlatego taki polityk władzę postrzega zazwyczaj nie jako cel, ale jako środek do realizacji tego, czego jeszcze nikt przed nim nie zrealizował. Do osiągnięcia tego celu polityk potrzebuje olbrzymiej, często nawet absolutnej władzy, o którą walczy. A kiedy udaje mu się tę władzę wywalczyć, stara się ją wykorzystać tak, aby jego ideały były urzeczywistnione dzięki jego własnym wysiłkom. Polityk, który staje się władcą, musi się spieszyć. Jeśli się nie pospieszy, jego ideał może zostać odrzucony, niezrealizowany albo zrealizowany inaczej, niż chciał, to jest $\mathrm{w}$ jego mniemaniu w sposób zniekształcony. Poza tym taki władca dąży do tego, aby zapisać się w historii jako pierwsza osoba, której udało się ucieleśnić w praktyce ten swój ideał. I pragnie on uwierzyć, że moralny cel uświęca niemoralne środki. Aleksander Macedoński i Cezar, Robespierre i Kalwin, Napoleon i Bismarck albo Lenin ze Stalinem i Hitler z Mussolinim pragnęli stworzyć wyobrażone przez nich idealne społeczeństwa i robili wszystko, co było w ich mocy, aby te idealne społeczeństwa zostały stworzone w wyniku ich osobistych działań. Z tego powodu sięgali po środki wojennej i ludobójczej likwidacji oraz najbrutalniejszych represji, usuwając z drogi historii wszystkie przeszkody, które w ich mniemaniu utrudniały im osiągnięcie tego świetlanego celu. Nie bez przyczyny mówi się, że dobrymi chęciami jest piekło wybrukowane - w tym właśnie tkwi podstawowy problem działacza politycznego. Tacy działacze zazwyczaj niczego nie żałują, a jeśli już mają poczucie winy, to tylko dlatego, że nie wykonali wszystkiego dokładnie, że nie byli wystarczająco wymagający i twardzi, że nie sięgnęli po radykalniejsze albo powściągliwsze środki, które pomogłyby uniknąć tego, co uznają za popełniony przez siebie błąd. Nie żałują niczego również tacy działacze polityczni, którzy nie mają żadnych ideałów politycznych i wykorzystują władzę przede wszystkim do kompensacji własnego kompleksu niższości. Władcy tego typu mogą być zarówno wielkimi krwiopijcami, jak Kaligula albo Neron, jak i całkiem nijakimi miernotami, jak Ludwik XV czy Breżniew. Wiele wyrzucał sobie, jak wiadomo, car Rosji Iwan Groźny. W ogóle władcy religijni są o wiele bardziej powściągliwi od tych, którzy Boga nie uznają. Gdyby Iwan nie był wierzącym chrześcijaninem i nie uznawał władzy Boga za wyższą od jego własnej, jego okrucieństwo najprawdopodobniej objawiłoby się w jeszcze straszniejszy sposób i może nawet zrównałoby się z okrucieństwem bezbożnych Lenina, Trockiego i Stalina. Stalin w rozmowie z twórcami filmu Iwan Groźny - Siergiejem Eisensteinem i Nikołajem Czerkasowem - krytykował „groźnego cara” za to, że zamiast zmiażdżyć wrogów państwa, stracił wiele czasu na bezsensowne wyrzuty sumienia. Unikalny pod tym względem jest historyczny przypadek imperatora rzymskiego Dioklecjana. Po tym, jak publicznie przyznał on, że nie udało się mimo wszystkich jego wysiłków zjednoczyć imperium rzymskiego, nadając wszystkim jego mieszkańcom jednakowe prawa obywatelskie, budując w Rzymie świątynie wszystkich religii i zamieniając Pax Romana 
na Status Romanus, podał się do dymisji i wycofał z życia publicznego. Jednak nie był to akt podyktowany skruchą albo poczuciem winy. Przypadek ten należałoby uznać za odrzucenie przez polityka wyznaczonego przez siebie celu, zrozumienie, że ideał jest nieosiągalny i że próba dalszego dążenia do niego jest zgubna. Okazało się, że Dioklecjan miał rację: po jego czasach, od IV wieku, imperium rzymskie zaczęło się rozpadać i niknąć.

V.D.: Ciekawi mnie, gdzie i kiedy człowiek kultury albo artysta trafia do opozycji, dajmy na to politycznej. Próbowałbym rozumować w następujący sposób: twórczość w swojej istocie jest przeżyciem kryzysowym, świadectwem krytycznego napięcia. Oznacza to bardzo głębokie odczucie grzechu, skruchy i winy - całego tego kompleksu. I artysta, jak sądzę, zawsze (najpierw) wchodzi w konflikt z tym systemem, przede wszystkim totalitarnym, który właśnie nie uznaje skruchy i winy. I wówczas kultura, prawdziwie twórcza kultura, dając świadectwo samej sobie, w istocie przeciwstawia się polityce totalitarnej.

A.Š.: Zapewne się z tym zgodzę, ale najpierw trzeba mieć totalitarne społeczeństwo. Proszę zauważyć, że totalitaryzm to dość rzadkie zjawisko, dość rzadko występujący w historii system polityczny - nie należy mylić totalitaryzmu z porządkami dyktatorskimi albo autorytarnymi. Totalitaryzm żąda od człowieka aktywnej i całkowitej niewoli. Dyktatury autorytarne pozostawiają człowiekowi sferę prywatną. Ludzie zachowują w takich dyktaturach prawa do prywatnej własności i prywatnej inicjatywy w sferze ekonomicznej - rolnicy pozostają właścicielami swojej ziemi i owoców swojej pracy, handlowcy bez przeszkód zarządzają swoimi sklepami i magazynami, prywatni fabrykanci i prywatne spółki akcyjne prowadzą firmy przemysłowe. Zazwyczaj nieskrępowane pozostają wolności religijne ludzi, ich działalność charytatywna i inne podobne inicjatywy społeczne. Dopóki ludzie działają w tych sferach i nie mieszają się do polityki, do sfery prerogatyw rządu, pozostawia się ich w spokoju. Polityka w takich dyktaturach autorytarnych jest zmonopolizowana, a życie prywatne odizolowane od polityki. Mamy tu do czynienia z przypadkiem tzw. pasywnej, częściowej niewoli, gdy ludziom zabrania się pewnej dziedziny działalności, zazwyczaj związanej z polityką. W dyktaturach totalitarnych - odwrotnie: od człowieka żąda się aktywnego wyrażania się we wszystkich dziedzinach, również w polityce, ale tylko w taki sposób, w jaki domaga się tego i uważa za słuszne totalitarna władza. W warunkach totalitaryzmu tworzy się bardzo wyjątkowa sytuacja egzystencjalna, gdy człowiek zobowiązany jest kłamać i robić nie to, czego sam chce, ale to, do czego zmusza go mówiąca rzekomo w jego imieniu władza. W takiej sytuacji sztuka rzeczywiście popada w bardzo krytyczne położenie, ponieważ z definicji jest nie tylko krytycznym stosunkiem wobec systemów opartych na dominacji, ale również wyrazem autentycznego stanu człowieka. I tak, jak autentycznego stanu człowieka nie można pogodzić z narzuconym mu i zupełnie nienaturalnym dla człowieka sposobem zachowania, tak sztuka nie może tolerować albo znieść narzuconej jej funkcji apologetycznej. Dlatego w warunkach totalitarnych sztuka - mówiąc o odrębnym człowieku, a nie o wszystkich ludziach w ogóle - koniecznie znajdzie się w opozycji do porządku autorytarnego. Zresztą w dyktaturze autorytarnej sztuka również znajdzie się w opozycji do porządku dyktatorskiego jedynie dlatego, 
że nie będzie mogła wyrazić frustracji człowieka, któremu zabrania się uzewnętrznić się jako istocie politycznej, jako człowiekowi, który czuje coś nie tylko wobec siebie i swoich bliskich, ale również wobec innych ludzi, wobec swojego narodu itp. Takie ograniczenie naturalnej ekspresji kolektywnej świadomości człowieka również spotyka się z odpowiednią - negatywną - reakcją artysty. Wszystkie systemy oparte na niewoli - pasywnej i aktywnej - nieuchronnie zatem wywołają opozycję artystów. Poza tym chciałbym powiedzieć, że nawet demokracja może być systemem niewoli, jeśli przejawia się jedynie jako władza większości i nie uznaje równych praw mniejszości. Jak Pan wie, dla Arystotelesa - z jakiegoś powodu wciąż wracam do Arystotelesa - najbardziej niesprawiedliwym i wynaturzonym porządkiem w systemie klasyfikacji porządków politycznych jest demokracja. Dlatego, że w przypadku demokracji jako władzy większości - w przeciwieństwie do władzy mniejszości - nawet nie trzeba dowodzić, że stara się ona działać dla dobra większości. Władza mniejszości jest z definicji ograniczona, gdy tymczasem władza większości może być otwarcie nieograniczona. Takiej władzy z łatwością przychodzi nie tylko ignorowanie interesów mniejszości, ale również odebranie jej elementarnych praw człowieka. Poza tym Arystoteles podkreśla, że każda odrębna jednostka również jest mniejszością, która nigdy do końca nie stopi się z większością i jej interesami. Dlatego nawet indywidualni członkowie rządzącej większości, gdy tylko zaczynają uzewnętrzniać się jako indywidualne podmioty, są temperowani przez władzę reprezentującą wolę tej większości i przemocą jej podporządkowywani. Najgorszym zatem porządkiem, według Arystotelesa, jest nieograniczona demokracja. Co oczywiste, taki porządek demokratyczny, w którym władza reprezentująca większość dyktuje swoją wolę jednostkom, również nie może podobać się artyście. Artysta także w tym wypadku będzie zatem w opozycji. Istotą sztuki jest to, że z całą wrażliwością reaguje ona na granice wolności pojedynczego człowieka, na te granice, które władza, czy nawet społeczeństwo, ustanawia dla jednostki, a które nie pozwalając jej na swobodny wyraz, stają się nie do zniesienia.

Chcąc zrozumieć człowieka i jego relację ze społeczeństwem, powinniśmy kierować się koncepcją homo duplex - albo podwójnego człowieka - Émile’a Durkheima. Zgodnie $\mathrm{z}$ tą koncepcją każdy człowiek jest z jednej strony odrębną jednostką, a więc indywidualistą dążącym przede wszystkim do zaspokojenia swoich własnych potrzeb duchowych i materialnych. Każdy człowiek ceni swoje życie oraz chce pozostawić niezatarty, indywidualny ślad nie tylko w bezpośrednim otoczeniu osobistym, ale być może również w historii narodu i świata. Jesteśmy ambitni i w ambicji wyraża się naturalny dla człowieka indywidualizm. Ale żeby człowiek mógł zrealizować te ambicje i pozostawić niezatarty ślad w otoczeniu, musi być również istotą społeczną, pozostającą w korelacji ze swoimi tzw. grupami referencyjnymi, do których adresuje swoje JA. Pragniemy należeć do pewnych struktur. Gdy zapytać człowieka, kim jest, nie tylko poda swoje nazwisko; powie też, że jest inżynierem albo tokarzem, prawnikiem albo pisarzem, jak również - że jest pochodzącym z Wilna albo Wiłkomierza Litwinem. W ten sposób określi siebie za pomocą wielu pojęć zbiorowych. Społeczeństwo i państwo, które potrafią zharmonizować i zaspokoić naturalne przejawy indywidualne i społeczne jednostki, jest dobrym społeczeństwem i państwem. Społeczeństwo i państwo, które 
tłamsi albo hamuje choćby jeden, a tym bardziej obydwa aspekty tej „podwójnej osobowości", jest złym społeczeństwem i państwem. Takie złe społeczeństwo i państwo, w których pozwala się na ujarzmienie albo prześladowanie jednego albo drugiego, a tym bardziej obydwu aspektów ludzkiej natury, niewątpliwie wywoła krytyczną reakcję artysty. Sztuka jest ważna społecznie dlatego, że zawsze odbiega od normy. Prawdziwej sztuce zawsze jest za ciasno w wąskich ramach kategorii normatywnych. Zawsze jest dysydencka, zawsze nowatorska. Wraz z przestępczością i innymi odstępstwami od normy sztuka jest jednym z najważniejszych motorów napędowych postępu społecznego. To, co dziś wydaje się godne potępienia, niemoralne albo inaczej wykraczające poza granice normy, z pomocą sztuki staje się akceptowalne i normalne w społeczeństwie jutra. Każdy postęp, duchowy czy społeczny, ugruntowuje się właśnie w taki sposób. Choćby wydawało się to dziwne, przestępczość i sztuka jest w tym sensie tym samym progiem funkcjonalnym społeczeństwa.

V.D.: Wracając do początku rozmowy: czy zgodziłby się Pan z myślą, że dla narodu, państwa czy dla pojedynczego polityka demokratyczna kultura jest konieczna oraz że (mimo wszystko) wówczas, gdy ta demokratyczna kultura staje się represyjna, nieunikniona i konieczna, staje się zarazem arystokratyczna?

A.Š.: Rzecz w tym, że na przykład wielcy twórcy demokracji amerykańskiej - Washington, Jefferson, Madison, Hamilton i inni - najbardziej obawiali się demokracji. Zawsze podkreślali, że tworzą nie demokrację, ale republikę, w której nie mogłaby się utworzyć jakaś specyficzna większość, będąca w stanie dyktować swoją wolę mniejszościom, przede wszystkim najważniejszej mniejszości - odrębnej jednostce. Konstytucja amerykańska jest prawdziwym kłębowiskiem podstępów. Celem federalnej struktury, podziału władzy na trzy części i zrównoważenia tych części, organizacji Kongresu, nadania prezydentowi ograniczonego prawa wetowania ustaw itp. było uniknięcie ekscesów demokracji. Sama idea reprezentacyjności władzy - zgodnie z którą elita zyskuje mandat wyborców i może realizować go zgodnie z własnym przekonaniem, a nie według tzw. mandatu imperatywnego, przyjętego przez marksistów, przeczących tym samym prawu przedstawiciela wyborców do osobistej wolności - nie pozwala bezpośrednio wyrażać się władczej woli większości i ciemiężyć mniejszości. W ten sposób Ameryka uniknęła dyktatury większości. Jak wspomniałem, Arystoteles mówił o demokracji jako najbardziej przerażającym i niesprawiedliwym porządku, ale twierdził również, że jeśli demokracja, która daje władzę większości, będzie zorganizowana w ten sposób, że władza ta będzie przede wszystkim bronić praw i interesów jednostek oraz mniejszości, a przez to dążyć do pełnej sprawiedliwości dla wszystkich - będzie najlepszym, idealnym porządkiem. Co prawda porządek taki nazywał on nie demokracją, ale politeja - przeciwieństwem demokracji. Twórcy systemu amerykańskiego tworzyli właśnie Arystotelesowskąpoliteję, ale ochrzcili ją nowoczesnym imieniem republiki. W ciągu dwóch stuleci, które minęły od czasu utworzenia USA, różnice pomiędzy pojęciami demokracji i republiki zostały zapomniane. Republika amerykańska zarówno przez samych Amerykanów, jak i ludzi z całego świata uważana jest za wzorzec demokracji. Jednak narody, które dopiero tworzą demokrację, nie mają prawa zapominać o tej różnicy. Powinny w pełni zrozumieć, że tworząc demokrację, przede wszystkim należy stworzyć porządek republikański (politeje). 
V.D.: Obecnie u nas (na Litwie) rzeczywiście odbywa się dziwny ruch, przejście z wieku mitologicznego do historycznego. Odkrywamy historię, historia się wtrąca, zaczynamy rozumieć, że większość sił ma skończony charakter i nie jest stworzona na wieki, o czym przekonywała nas cała historia utopijnego (i nie tylko) socjalizmu. I jednym $\mathrm{z}$ wykorzystywanych w ciągu tego czterdziestolecia sposobów na odnalezienie historii była twórczość, kultura, która jawi się jako kontynuacja historii. To jeden ze sposobów na odnalezienie historii. Czy zgodziłby się Pan, że innym sposobem, inną możliwością kontynuacji historii jest religia? I jak się Panu wydaje, na ile mogłaby ona być istotna w odnajdywaniu historii Litwy?

A.Š.: Wydaje mi się, że sztuki i religii nie da się oddzielić od historii, ponieważ utrwalone jest $\mathrm{w}$ nich podstawowe doświadczenie historyczne - to, co pozostaje $\mathrm{z}$ historii na wszystkie czasy. W tym sensie sztuka i religia, jako substraty historii, są od niej ważniejsze. Historia jest tylko zmianą, a to, co z historycznej zmiany pozostaje i tworzy historyczną ciągłość, staje się obiektami religii albo sztuki. Według Hegla najwyższą, syntetyczną formą objawienia się absolutnego ducha jest filozofia, a religia i sztuka są tezą i antytezą tej filozoficznej syntezy. Gdy spojrzy się z takiej heglowskiej perspektywy na to, co w ostatnich dziesięcioleciach działo się na Litwie, wydaje się, że do filozofii jako syntezy jeszcze nie dojrzeliśmy; mamy jedynie ten jeszcze niezsyntetyzowany system tezy-antytezy, wyraz absolutnego ducha właśnie poprzez sztukę i religię. Sztuka i religia były jedynymi duchowymi drogowskazami, na które naród mógł orientować się jako na portret swojej wieczności. Co jest ważniejsze - sztuka czy religia? Religia oczywiście. Religia w ogóle jest najważniejszym rodzajem ekspresji człowieka. W mojej opinii (i tutaj różnię się od Hegla) filozofia tylko wtedy może stać się najwyższym przejawem ducha, gdy jest filozofią religii. Ateistyczne albo agnostyczne (nieprzekonane o istnieniu Boga) systemy filozoficzne nieuchronnie stają się niewiele wartymi surogatami religii, pseudoreligiami albo religiami świeckimi. Pamięta Pan zapewne spór Marksa z francuskim socjalistą Louisem Blankiem, podczas którego Blanc próbował dowieść Marksowi, że ateistyczny światopogląd tego ostatniego jest całkowitym bublem. Marks odpowiedział wówczas: Po co mi religia, jeśli świat można w petni wyjaśnić za pomoca nauki, na co Blanc się odciąt: Ateizm jest wtaśnie Pana religia, Panie Marks. W genetycznej naturze człowieka istnieją dwa najważniejsze elementy duchowe. Pierwszym jest język, zdolność do wyrażania skomplikowanych myśli za pomocą form gramatycznych. Język może być litewski, rosyjski, chiński albo angielski, ale wszystkie te języki są jedynie formami uzewnętrzniania się jednorodnej struktury genetyczno-gramatycznej. Zdeterminowana genetycznie umiejętność mówienia, wyrażania myśli za pomocą skomplikowanych, ale i zrozumiałych dla innych form gramatycznych czyni nas ludźmi. To zresztą również myśl Arystotelesa. Twierdził on, że od innych zwierząt odróżnia nas to, że potrafimy w językowy sposób rozważać problemy dobra i zła, sprawiedliwości i kłamstwa, czego nie potrafi żadne inne stworzenie. Drugim takim genetycznie wrodzonym elementem duchowym jest religia. Pośród wszystkich innych zwierząt jedynie człowiek wie, że jest tylko chwilowym mieszkańcem tej ziemi i nieuchronnie umrze. $\mathrm{Z}$ tego powodu odczucie świata przez człowieka jest odczuciem istoty tymczasowo wrzuconej do świata, który został stworzony przed jego przyjściem i który pozostanie 
po jego odejściu. Pod wpływem tego odczucia człowiek próbuje odgadnąć, jaki jest sens jego tymczasowego bycia w tym świecie, jaki ma cel i związek z wiecznością, z tym, który ten świat stworzył i umieścił w nim człowieka. I ta pierwotna, nieunikniona myśl jest w istocie przejawem religijnej natury człowieka. Dla człowieka od samego początku jasne jest, że nie może być sensem swojej własnej egzystencji, że ten sens znajduje się poza granicami jego własnej osobowości i służy celom Wszechmocnego, Twórcy tego świata. Jak powiedział Kierkegaard, kultura rodzi się właśnie z tego pierwszego świadomego krzyku człowieka: „Kim jesteś, Boże?” - ponieważ w momencie, w którym powstaje to pytanie, pojawia się sztuka, która przez cały czas stara się udzielić odpowiedzi, ale nigdy nie jest i nie będzie w stanie tego uczynić ostatecznie. W historii różnie próbowano odpowiedzieć na pytanie: „Kim jesteś, Boże?”. Niektórzy myśliciele, ateiści, negowali Boga, ogłaszając, że świat materialny jest wieczny i absolutny. Jednak również tacy myśliciele ateiści byli w istocie religijni. Tylko zamiast Boga absolutyzowali i nadawali status bóstwa świeckim wartościom ludzkim - wiecznemu człowieczeństwu albo pewnej grupie w obrębie ludzkości. Dla Nietzschego taką absolutną wartością była silna, władcza i twórcza elita - Herrenvolk, dla Marksa - społeczeństwo komunistyczne, stworzone poprzez walkę klas i odsłaniające do końca potencjał twórczy wszystkich ludzi; dla Hitlera - potrafiąca tworzyć wartości kulturalne w wymiarze globalnym rasa aryjska i porządek świata oparty na jej dominacji; dla różnej maści ideologów ateistycznego nacjonalizmu - ich własny naród. Według myślicieli ateistów ludzie służący tym deifikowanym wartościom i całkowicie im oddani mieli nadać znaczenie swojej egzystencji na ziemi i w ten sposób zaspokoić swoją genetycznie zaprogramowaną religijność. Jak widać, Blanc miał słuszność, zarzucając Marksowi, że ateizm jest dla niego religią. Nie trzeba zapewne nawet wyjaśniać, że wszystkie te naruszające pierwsze przykazanie Boże świeckie pseudoreligie były i pozostają niebezpiecznymi herezjami, pod przykrywką których popełniono największe zbrodnie wobec Boga i ludzi. Takimi herezjami mogą stać się nawet autentyczne ideologie religijne, jeśli ich ideolodzy uważają siebie za jedynych prawdziwych i równych Bogu wyrazicieli Jego woli. Wielki inkwizytor Torquemada, Savonarola, Kalwin i ajatollah Chomeini są wyrazistymi przykładami takich religijnych ideologów, którzy naruszyli pierwsze przykazanie.

V.D.: Czy uznałby Pan religię za część składową kultury?

A.Š.: Ona jest częścią składową kultury, ale krzyk człowieka wzywającego Boga pojawił się wcześniej niż kultura i w ten sposób zdeterminował jej utworzenie i rozwój. Religia jest naturalną potrzebą człowieka, a kultura i sztuka są jedynie sposobami na zaspokojenie tej naturalnej potrzeby. Weźmy na przykład sztukę antyczną. W całości była ona związana z mitologią religijną. Biblia również jest dziełem sztuki, zapewne jednym z najdoskonalszych pomników artystycznej twórczości człowieka. Sztuka biblijna również bezpośrednio odpowiada na potrzebę religijną człowieka. Odejścia w ateizm, te - by tak rzec - renesansowe wzloty, świadczące jakoby o tym, że człowiek jest samowystarczalny i nie potrzebuje Boga, prowadzą do deifikacji człowieka. Chrześcijaństwo ogłosiło Chrystusa Bogoczłowiekiem i w ten sposób zbliżyło pojęcie boskości do człowieka, a renesans, zabijając boskość Chrystusa, zamienił człowieka w Boga. Obecnie znajdujemy się w wynikającej z renesansowego światopoglądu duchowej ślepej uliczce. 
Po niemal siedmiu wiekach, które minęły od początku renesansu, kulturę Europy znów ogarnął duchowy kryzys. Po przejściu przez wiele różnych, deifikujących człowieka religijnych pokus - marksizm jest tylko jedną z wielu odmian takich pokus, którą mieliśmy „,szczęście” doświadczyć na własnej skórze - kultura ta znów stanęła przed drzwiami autentycznej religii i - jestem pewien - w XXI wieku szeroko te drzwi otworzy. Nie wiadomo, czy ludzkość w ogóle będzie w stanie przetrwać, jeśli tego nie zrobi. Historia, jak się zdaje, rozwija się ruchem wahadłowym: z początku człowiek poszukuje swojego sensu poprzez Boga, którego próbuje zobrazować i zrozumieć w procesie kulturowym. Równocześnie do takich poszukiwań duchowych człowiek udoskonala materialny aspekt swojego życia, wynajduje łuki i strzały, uczy się kontrolować ogień, na którym piecze w ten czy inny sposób zabite zwierzę itd. Człowiek, który poczynił znaczący postęp materialny, zaczyna czuć się tak potężnym, że nie potrzebuje już Boga - samemu sobie wydaje się równym Bogu władcą natury. W ten sposób wahadło historii zaczyna oddalać się od poszukiwań duchowych człowieka w stronę bieguna jego powiększającej i utwierdzającej się materialnej potęgi. Dzieje się tak, aż w wyniku kryzysów i wojen staje się jasne, że materialny postęp sam w sobie tworzy więcej problemów, niż rozwiązuje. Wówczas człowiek znów zadaje sobie pytanie: dlaczego to wszystko robiłem, jaki jest duchowy cel i sens tego mojego materialnego wzlotu. Wahadło historii w takim momencie ponownie zwraca się ku poszukiwaniom duchowym i egzystencji religijnej. Obecnie, u progu XXI wieku, wyczerpaliśmy zapewne ten renesansowy pierwiastek materialistyczny, który swój początek miał w XIV-XV wieku, i ponownie wracamy do poszukiwań ducha, znów orientujemy się na religię i religijne wartości.

V.D.: Czy zgodziłby się Pan z myślą, że litewskie pragnienie powrotu do Europy jest zarazem pragnieniem powrotu do Europy chrześcijańskiej?

A.Š.: Trudno mi powiedzieć, czego chce Litwa. Zapewne mógłby Pan powiedzieć więcej na ten temat niż ja, ale wydaje mi się, że Litwa przede wszystkim pragnie wyrwać się z objęć imperium Rosji, a dokąd się z nich wyrwie - to już nie tak ważne. Wydaje mi się, że Europa jest u nas idealizowana. Pojęcia Europy używamy najczęściej jako zamiennika pojęcia dobra. Dla nas Europa jest tam, gdzie jest dobrze, spokojnie, panuje cywilizacja, a ludzie żyją dostatnio i kulturalnie, tj. nie obijają jedni drugim pysków i nie piją wódki do upadku i zaśnięcia w błocie. Oznacza to, że chcemy wrócić do dobrego, normalnego życia, którego symbolem w naszych oczach jest Europa. Wydaje mi się również, że nasz pociąg do Kościoła podyktowany jest nie tylko przez ten powszechny, prowadzący ludzkość z powrotem do Boga proces, o którym mówiłem wcześniej. Gdyby to był podstawowy impuls naszego religijnego odrodzenia, powiedziałbym niewątpliwie, że Litwa pragnie powrotu do chrześcijańskiej Europy. Uważam jednak, że Litwa poprzez religię i tradycję kościelną dąży przede wszystkim do odnalezienia i zrozumienia samej siebie jako narodu, bowiem jedynie w religii i Kościele naród odnajduje dziś tę namacalną nić, która wiąże go $\mathrm{z}$ autentyczną tradycją narodową, z ciągłością historyczną narodu. Litwa nie jest jeszcze normalnym państwem i narodem. Litwa dopiero staje na nogach i dzieje się to z wielkim trudem. A gdy trudno stanąć na nogach, wszystkie podpory wyglądają dobrze - i Kościól, i Europa, i wszystko inne, co nawinie się pod rękę. Jednak nie jest to jeszcze dążenie do życia w chrześcijańskiej Europie; sądzę, że jeszcze do tego nie dojrzeliśmy. 
V.D.: Na początku powiedzieliśmy, że w nieistniejącym państwie, jak to było w naszym przypadku, kultura czasem prześciga politykę i ekonomię. Dlatego zawsze a zwłaszcza obecnie - bardzo aktualne jest pytanie o to, w jakim kierunku będzie się ona rozwijać i dojrzewać, ile będzie w stanie dać innym kulturom, a ile weźmie dla siebie.

A.Š.: W swojej wydrukowanej w czasopiśmie "Sietynas” odpowiedzi na ankietę „Naujoji Romuva” wspominałem, że aby Litwa, która wybrnęła z radzieckiej kałuży, utwierdziła swoją obecność w Europie i na świecie, powinna nakreślić sobie bardzo ambitne plany kulturalne i twórcze. Litwini powinni przestać uważać się za mały, prowincjonalny naród, którego jedynym przeznaczeniem jest podążanie za przykładem innych, większych, bardziej doświadczonych i obytych narodów. Uważam, że gdyby Litwa stanowczo wyzbyła się kompleksu małego narodu, mogłaby stać się narodem naprawdę wielkim, nadającym ton całemu światu. Historia przetrwania Litwy jako narodu stojącego u progu wymarcia jest unikalna i powinna być odważnie komunikowana całemu światu. Tragiczne, a zarazem heroiczne doświadczenia Litwy są bardzo potrzebne światu, który może się z tych doświadczeń wiele nauczyć i wiele sobie uświadomić. W wielu aspektach możemy zatem stać się pionierami na skalę świata, a nie tylko pozostawać jego imitatorami. Być może teraz, gdy jeszcze nie stoimy pewnie na nogach, trochę za wcześnie, aby mówić o takiej pionierskiej roli Litwy. Ale kiedy już staniemy, nasze odpowiedzi na coraz bardziej aktualne na świecie pytanie: „Kim jesteś, Boże?” może być usłyszane i przyjęte przez całą ludzkość jako przestroga, o której należy pamiętać.

V.D.: Czy zauważył Pan, że Litwa ma obecnie nie tylko ambitnych artystów, ale również ambitnych polityków, którzy pragną stać się profesjonalistami?

A.Š.: Tak, zauważam ich i niezmiernie się z tego cieszę. Ludzie, których spotkałem tutaj, podczas sympozjum w Chicago, naprawdę poważnie zaznaczyli swoje pragnienie politycznego kierownictwa narodem litewskim. Szczególnie cieszy mnie, że widzę takich intelektualistów światowej skali, jak szanowni Landsbergis ${ }^{4}$ i Ozolas ${ }^{5}$, którzy stają się najbardziej profesjonalnymi politykami litewskimi. A jeszcze ważniejsze jest, jak sądzę, że ludzie pokroju Landsbergisa i Ozolasa przez cały naród uznawani są za jego autentycznych przedstawicieli, ludzi godnych zaufania i politycznych liderów. To, że naród uznaje wyrosłych na jego gruncie intelektualistów i powierza im polityczne kierownictwo, jest dla mnie ważną rękojmią, gwarantującą, że potencjalna pionierska rola wolnej Litwy na świecie wkrótce może zostać zrealizowana.

V.D.: Dziękuję za rozmowę.

„Krantai”, lipiec-sierpień 1990 r.

Tłumaczenie z języka litewskiego Kamil Pecela

$4 \quad$ Vytautas Landsbergis (ur. 1932) - polityk i muzykolog, przywódca Ruchu Niepodległości Litwy Sąūdis; prezydent Litwy w latach 1990-1992.

5 Romualdas Ozolas (1939-2015) - polityk, filozof i filolog; jeden z założycieli Sąjūdisu; wicepremier Litwy w latach 1990-1991. 